\title{
Evaluation of Cervical Posture of Adolescent Subjects in Skeletal Class I, II, and III
}

\author{
Evaluación de la Postura Cervical en Sujetos Adolescentes con Clase Esqueletal I, II y III \\ "Nerilda García; **Antonio Sanhueza; ${ }^{* * *, * * * *}$ Mario Cantín \& ${ }^{* * * *}$ Ramón Fuentes
}

GARCÍA, N.; SANHUEZA, A.; CANTÍN, M. \& FUENTES, R. Evaluation of cervical posture of adolescent subject in skeletal class I, II, and III. Int. J. Morphol., 30(2):405-410, 2012.

SUMMARY: The aim of this study was to investigate whether there are significant differences in cervical posture in adolescent subjects with a different skeletal class. Twenty-eight adolescent subjects (21 boys and 7 girls, average age of 13.6 years, SD \pm 3.2 ) who were admitted for orthodontic treatment were included in this study. Selection criteria were as follows: no previous orthodontic, orthopaedic, or surgical treatment and absence of facial asymmetry, bruxism, nasal obstruction, orofacial pain, and temporomandibular joint dysfunction. Lateral skull radiographs were taken, and the subjects were divided into three groups based on their skeletal class according to ANB angle and Wits appraisal. The cephalometric tracings included cervical postural variables and cervical curvature. By Pearson's correlation analysis (using the variables as continuous), we found a high linear relationship between the variables angle ANB and Wits appraisal (0.7895) and between cervical curvature and $\mathrm{C} 0-\mathrm{C} 1$ distance (0.6384). Statistical significance was observed between ANB angle and cervical curvature $(\mathrm{p}=0.039)$ and $\mathrm{C} 0-\mathrm{C} 1$ distance $(\mathrm{p}=0.045)$ variables, whereas Wits appraisal showed no significant association with any study variable $(\mathrm{p}$ $>0.05)$. The cervical curvature was different between the groups; however, both averages turned out to have more characteristics of rectified cervical, being female clearly the most affected, as well as an average lower than the standard posterior-inferior angle, which shows a more posterior rotation of the skull. The cervical posture seems to be strongly associated with the sagittal posture as well as the vertical structure of the face, with these data being complementary to other determinants of craniofacial growth and development.

KEY WORDS: Cervical posture; Skeletal class; Craniocervical abnormalities; Cervical curvature.

\section{INTRODUCTION}

The stomatognathic system consists of structures directly related to the head and cervical spine. Alterations in the anatomical elements, nervous or their interconnections have the potential to influence reciprocally (Friedman \& Weisberg, 2000), resulting in postural changes related to the development of different structures and malocclusions (Bergamini et al., 2008).

Posture is defined as the ratio of a segment or part of the body in relation to an adjacent and between all segments of the human body (Gonzalez \& Manns, 1996). Cervical posture appears to be strongly associated with vertical and sagittal facial dimensions and cervical spine in children with skeletal class III, significantly more than children with class I and II, and with greater extension of the head in the middle segment of the spine in skeletal class II patients (D'Attilio et al., 2005). For Solow \& Sonnesen (1998), this also is associated with dental crowding, facial abnormalities (Scutellari et al., 1990; Santander et al., 2000), parafunctions, and permeability of the upper airway (Amis et al., 1999). According to Rocabado (1984), there is little assessment of orthostatic stability evaluation of the skull on the cervical spine in children and adults.

Studies on adult subjects in the Region of Araucania recorded changes in cervical curvature in $70 \%$ of cases (kyphotic 35\%, rectified 33.3\%, and $1.7 \%$ lordotic), in hyoid triangle in $68 \%$ of cases (at the plane $31.7 \%$, invested in $37 \%)$, and $\mathrm{C} 0-\mathrm{C} 1$ distance in $48 \%$ of cases $(15 \%<4 \mathrm{~mm}$ and $33 \%>9 \mathrm{~mm})$. In addition, posterior-inferior angle changes have been observed in $40 \%$ of cases $\left(<96^{\circ}\right.$ in $30 \%$ and $>106^{\circ}$ in 10\%) (Fuentes et al., 1996), which shows a high percentage of altered orthostatic stability in the craniocervical region.

\footnotetext{
* Alumna del Programa de Magíster en Odontología, Universidad de La Frontera, Temuco, Chile.

** Departamento Matemáticas y Estadística, Universidad de La Frontera, Temuco, Chile

*** Departamento Odontología Integral, Universidad de La Frontera, Temuco, Chile.

**** Programa de Doctorado en Ciencias Morfológicas, Universidad de La Frontera, Temuco, Chile.
} 
Huggare (1998) referring to disorders of posture and dentofacial morphology concludes that there is credible evidence of increased prevalence of Angle class II malocclusion-associated hyperlordosis of the cervical spine and increased risk of lateral crossbite in children affected with scoliosis and torticollis.

In relation to this background, the objective of this study was to describe the angular relationship of the skull on the cervical spine (neck position) and the stability of it and investigate whether there are significant differences in adolescent patients with skeletal class I, II, or III attending the Dental Clinic of the Universidad de La Frontera during the period 2010-2011.

\section{MATERIAL AND METHOD}

We conducted a cross-sectional research, whose recruitment period was from April to July 2011. We used a probabilistic sample consisting of consecutive adolescent subjects in late mixed and permanent dentition examined inthe Orthodontic Teaching Unit Dental Clinic of the Universidad de La Frontera. All guardians expressed their informed consent to participate in the study. Subjects were excluded who had previous orthodontic, orthopedic, or surgical orthognathic treatments; facial asymmetry; bruxism; nasal obstruction; presence of pain in the head, neck, and face; and signs and symptoms of temporomandibular disorders.

To determine the skeletal class, assessment was conducted through cephalometric measurements of i) ANB angle of Steiner (Gregoret, 1997) and ii) Wits appraisal (Jacobson, 1975) on standard lateral cephalometric radiograph. Each of the parameters was established as follows:

ANB angle (analysis of the jaw relationship): corresponding to the angle formed by the $\mathrm{A}, \mathrm{N}$, and $\mathrm{B}$ points joining. It indicates the relationship of the bony bases, allowing us to determine skeletal angle class. The normal value is $2^{\circ}$ to $4^{\circ}$ (class I). A larger angle of $4^{\circ}$ indicates a tendency to class II, and a smaller angle of $2^{\circ}$ indicates a class III tendency (Fig. 1).

Wits appraisal: linear measurement discrepancy between the maxilla and mandible directly to the occlusal plane. It projects points A and B perpendicular to the occlusal plane and measures the distance between two points. The normal value is $0 \mathrm{~mm}$ in the female group and (-) $1 \mathrm{~mm}$ in the male group, where the point A would be $1 \mathrm{~mm}$ behind the point
B. In class I, the projection of points A and B generally in agreement, whereas in class II, the projection of point $\mathrm{B}$ from point $\mathrm{A}$ would be behind giving a positive value, and in class III, the projection of point B ahead of A would be giving a negative value (Fig. 1).

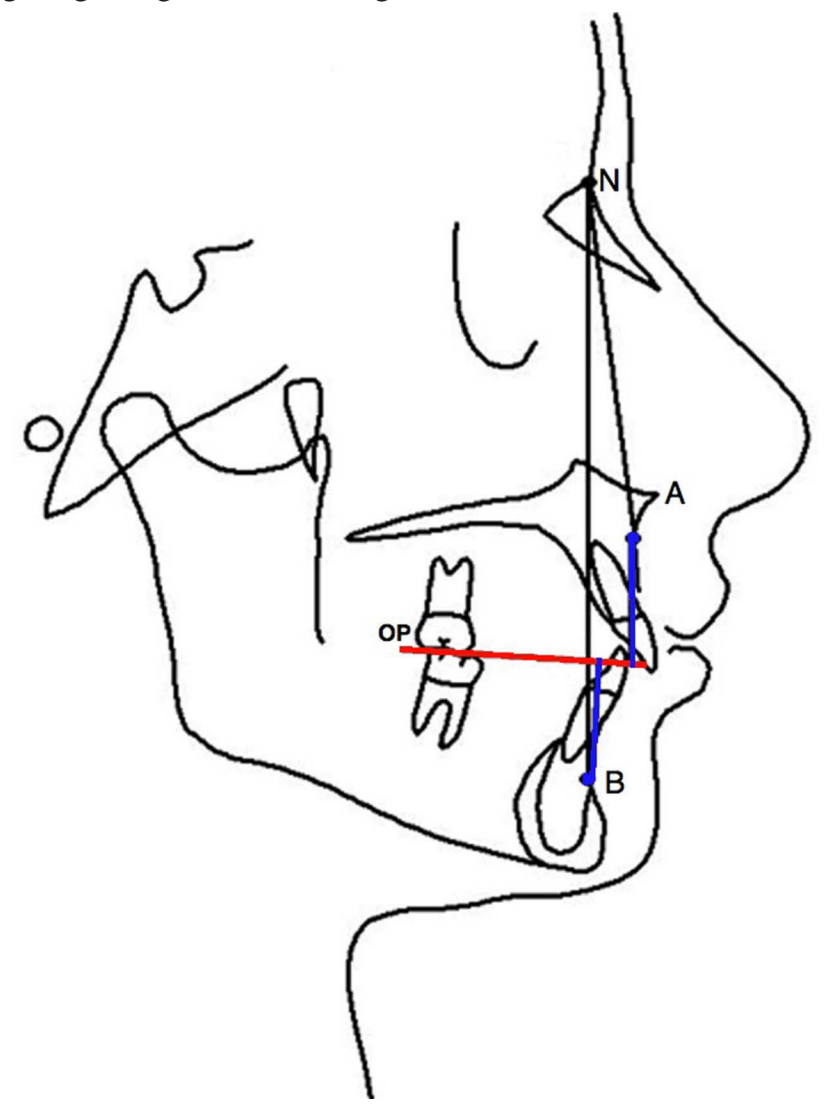

Fig. 1. Scheme used to determine the skeletal classes as for cephalometric measurements: Steiner's ANB angle and Wits appraisal on standard lateral cephalometric radiograph. $\mathrm{OP}=$ Occlusal plane, $\mathrm{N}=$ Nasion, $\mathrm{A}=$ Subspinale and $\mathrm{B}=$ Supramentale.

The following were determined after cervical posture was evaluated (Fig. 2) using radiographs in natural head position through biomechanical cervical skull analysis, as recommended by Rocabado: the posterior-inferior angle, $\mathrm{C} 0$ $\mathrm{C} 1$ distance, and position of the hyoid triangle. Finally, the cervical curvature was assessed using the technique described by Penning (1968).

All measurements were performed by a single trained operator blind to the study, which were repeated a week later . The collection of all radiographs was performed with the Bluex Imagen STI Panceph Pantos 16. Magnification distortion of the equipment was considered and accounted to $11 \%$.

Statistical analysis was performed using descriptive statistics, considering frequency distribution tables, 
averages, means, and standard deviations. For the inferential analysis, the following were used: the chi-square, Student's t, and Wilcoxon Mann-Whitney tests. The analysis of reliability is used to calculate the intraclass correlation using a significance level of $5 \%$.

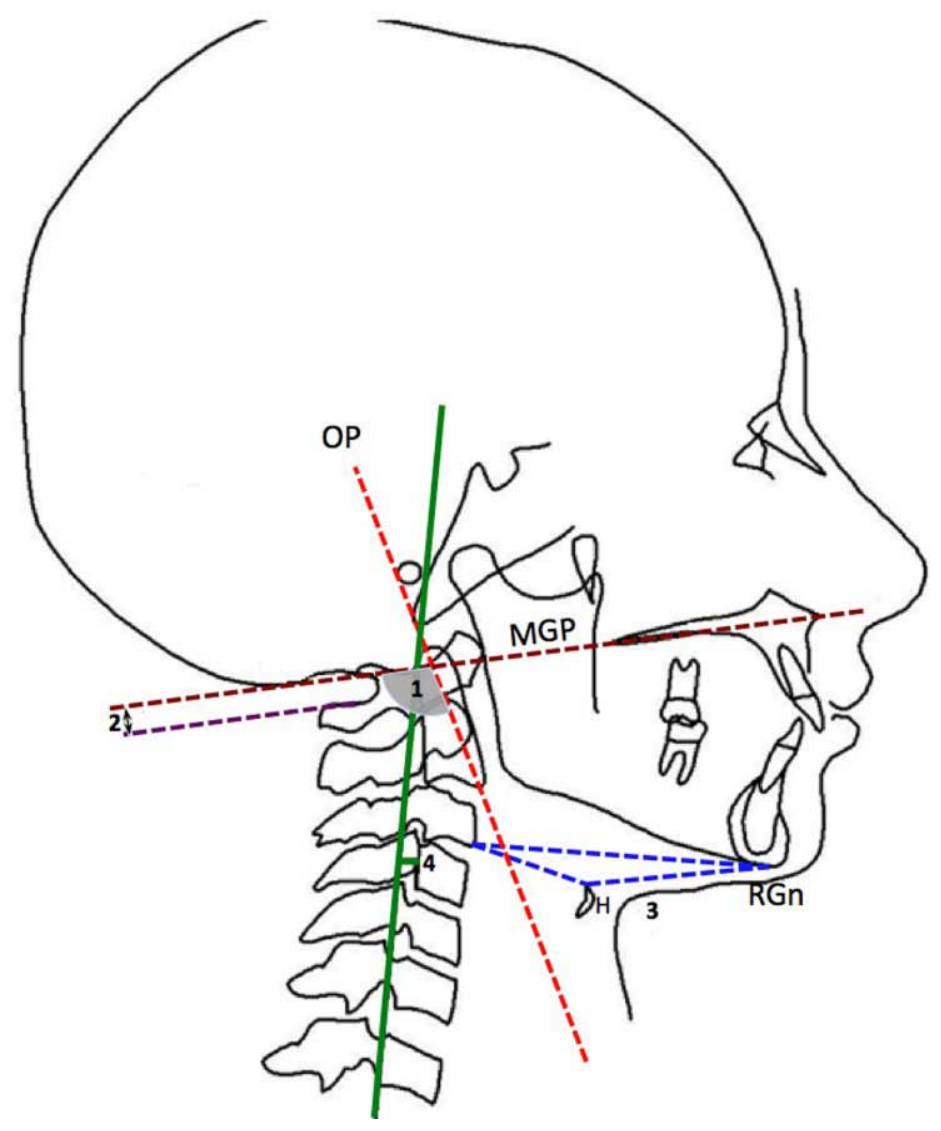

Fig. 2. Scheme for cervical postural assessment on radiographs in natural head position through the biomechanical Cervical Skull Rocabado Analysis. $1=$ posterior-inferior angle, $2=\mathrm{C} 0-\mathrm{C} 1$ distance, $3=$ hyoid triangle and $4=$ cervical curvature. $\mathrm{MGP}=\mathrm{McGreg}$ or plane, $\mathrm{OP}=$ Odontoid plane, $\mathrm{RGn}=$ Retrognation.

\section{RESULTS}

The sample consisted of 28 subjects ( 21 boys and 7 girls), whose average age was 13.6 years ( $\mathrm{SD} \pm 3.25$.) The average age by sex was 14.04 years $(\mathrm{SD} \pm 3.52)$ for the male patients and $12.57(\mathrm{SD} \pm 2.07)$ for the female patients.

In determining the skeletal class according to the ANB angle, a sample consisted of 10 subjects in skeletal class I, 15 subjects in skeletal class II, and 3 subjects in the skeletal class III, whereas according to the Wits appraisal, there were 10 subjects in skeletal class I, 12 subjects in skeletal class II, and 6 subjects in skeletal class III. The study variables are described in Tables I and II.
Table I. Description of cephalometric variables identified in the sample.

\begin{tabular}{lcc}
\hline Variables & Mean & SD \\
\hline Cervical curvature & 5.196 & 4.236 \\
C0-C 1 distance $(\mathrm{mm})$ & 7.767 & 2.865 \\
Posterior-inferior angle & 101.678 & 6.857 \\
'on & 4.375 & 3.510 \\
Wits appraisal $(\mathrm{mm})$ & 0.160 & 4.934 \\
\hline
\end{tabular}

Table II. Distribution of the hyoid triangle variable by sex in the total sample.

\begin{tabular}{lccc}
\hline \multirow{2}{*}{ Sex } & \multicolumn{3}{c}{ Hyoid triangle } \\
\cline { 2 - 4 } & Positive & Negative & In the plane \\
\cline { 2 - 4 } & $\mathrm{n}(\%)$ & $\mathrm{n}(\%)$ & $\mathrm{n}(\%)$ \\
\hline Male & $6(28.57)$ & $8(38.09)$ & $7(33.33)$ \\
Female & $0(0.00)$ & $5(71.43)$ & $2(28.57)$ \\
\hline
\end{tabular}

When comparing variables by sex, cervical curvature and the posterior-inferior angle were found to have a statistically significant association. Although both sexes were found to have characteristics of a corrected cervical spine, the female subjects had more severe cases. Also, regarding the posterior-inferior angle, the group of female subjects showed greater posterior rotation; the average value was observed in the male group, higher than the norm, whereas the lowest value was found in the female group but within the parameters of the standard. The comparison of these variables according to sex is shown in Table III. To improve the analysis is categorized in normal and abnormal postural variables. The association between skeletal class action through ANB angle and Wits appraisal and cervical variables described in Tables IV and V showed a statistical significance between ANB angle and cervical curvature $(\mathrm{p}=0.039)$ and $\mathrm{C} 0$ C1 distance $(\mathrm{p}=0.045)$ variables, whereas Wits appraisal showed no significant association with any study variable $(\mathrm{p}>0.05)$.

By Pearson correlation analysis (using the variables as continuous), we found a high linear relationship between the ANB angle and Wits appraisal variables $(0.7895)$ and between cervical curvature and $\mathrm{C} 0$ - $\mathrm{C} 1$ distance variables (0.6384), inversely proportional between the variables ANB angle and cervical curvature (-0.4328).

In determining the reliability, intraclass correlation values were obtained for variables cer- 
vical curvature with $0.99(\mathrm{p}=0.096), \mathrm{C} 0-\mathrm{C} 1$ distance with angle with $0.98(\mathrm{p}=0.99)$, and Wits appraisal with $0.99(\mathrm{p}=$ $0.99(\mathrm{p}=0.7690)$, posterior angle with $0.99(\mathrm{p}=0.69)$, ANB $\quad 0.5731)$.

Table III. Comparison of variables according to sex. *statistically significant association (T-Test); **median value (Mann-Whitney and Wilcoxon).

\begin{tabular}{|c|c|c|c|c|c|}
\hline \multirow{3}{*}{ Variables } & \multicolumn{4}{|c|}{ Sex } & \multirow[t]{3}{*}{ p-Value } \\
\hline & \multicolumn{2}{|c|}{ Male } & \multicolumn{2}{|c|}{ Female } & \\
\hline & Mean & SD & Mean & SD & \\
\hline Cervical curvature $(\mathrm{mm})$ & 6.119 & 4.153 & 2.428 & 3.371 & $0.043^{*}$ \\
\hline $\mathrm{C} 0-\mathrm{C} 1$ distance & 8.023 & 3.096 & 7.000 & 2.020 & 0.423 \\
\hline Posterior-inferior angle & 104.166 & 5.816 & 94.214 & 3.486 & $0.000^{*}$ \\
\hline ANB angle & 4.238 & 0.804 & 4.785 & 1.467 & 0.728 \\
\hline Wits appraisal & $-0.5 * *$ & 5.486 & $2.142 * *$ & 1.772 & 0.229 \\
\hline
\end{tabular}

Table IV. Association between ANB angle and cervical curvature, $\mathrm{C} 0$-C1 distance, posterior-inferior angle, hyoid triangle variables. *statistically significant association (Chi-square test).

\begin{tabular}{|c|c|c|c|c|c|c|c|c|}
\hline \multirow{3}{*}{ Skeletal class } & & \multicolumn{6}{|c|}{ ANB Angle (\%) } & \multirow{3}{*}{$\mathrm{p}$-Value } \\
\hline & & \multicolumn{2}{|c|}{ Class I } & \multicolumn{2}{|c|}{ Class II } & \multicolumn{2}{|c|}{ Class III } & \\
\hline & & $\%$ & $\mathrm{n}$ & $\%$ & $\mathrm{n}$ & $\%$ & $\mathrm{n}$ & \\
\hline \multirow[t]{2}{*}{ Cervical curvature (mm) } & Abnormal & 26.32 & 5 & 73.68 & 14 & 0.00 & 0 & $0.039 *$ \\
\hline & Normal & 44.44 & 4 & 33.33 & 3 & 22.22 & 2 & \\
\hline \multirow[t]{2}{*}{$\mathrm{C} 0-\mathrm{C} 1$ distance } & Abnormal & 10.00 & 1 & 70.00 & 7 & 20.00 & 2 & $0.045^{*}$ \\
\hline & Normal & 44.44 & 8 & 55.56 & 10 & 0.00 & 0 & \\
\hline \multirow[t]{2}{*}{ Posterior-inferior angle } & Abnormal & 20.00 & 3 & 66.67 & 10 & 13.13 & 2 & 0.182 \\
\hline & Normal & 46.15 & 6 & 53.85 & 7 & 0.00 & 0 & \\
\hline \multirow[t]{2}{*}{ Hyoid triangle } & Abnormal & 27.27 & 6 & 67.64 & 14 & 9.09 & 2 & 0.485 \\
\hline & Normal & 50.00 & 3 & 50.00 & 3 & 0.00 & 0 & \\
\hline
\end{tabular}

Table V. Association between Wits appraisal and cervical curvature, C0-C1 distance, posterior-inferior angle, hyoid triangle variables. Chi-square test.

\begin{tabular}{|c|c|c|c|c|c|c|c|c|}
\hline \multirow{3}{*}{ Skeletal class } & & \multicolumn{6}{|c|}{ Wits appraisal (\%) } & \multirow[t]{3}{*}{ p-Value } \\
\hline & & \multicolumn{2}{|c|}{ Class I } & \multicolumn{2}{|c|}{ Class II } & \multicolumn{2}{|c|}{ Class III } & \\
\hline & & $\%$ & $\mathrm{n}$ & $\%$ & $\mathrm{n}$ & $\%$ & $\mathrm{n}$ & \\
\hline \multirow[t]{2}{*}{ Cervical curvature (mm) } & Abnormal & 26.32 & 5 & 52.63 & 10 & 21.05 & 4 & 0.273 \\
\hline & Normal & 33.33 & 3 & 22.22 & 2 & 44.44 & 4 & \\
\hline \multirow[t]{2}{*}{$\mathrm{C} 0-\mathrm{C} 1$ distance } & Abnormal & 30.00 & 3 & 40.00 & 4 & 30.00 & 3 & 0.974 \\
\hline & Normal & 27.78 & 5 & 44.44 & 8 & 27.78 & 5 & \\
\hline \multirow[t]{2}{*}{ Posterior-inferior angle } & Abnormal & 26.67 & 4 & 46.67 & 7 & 26.67 & 4 & 0.908 \\
\hline & Normal & 30.77 & 4 & 38.46 & 5 & 30.77 & 4 & \\
\hline \multirow[t]{2}{*}{ Hyoid triangle } & Abnormal & 31.82 & 7 & 45.45 & 10 & 22.73 & 5 & 0.413 \\
\hline & Normal & 16.67 & 1 & 33.33 & 2 & 50.00 & 3 & \\
\hline
\end{tabular}




\section{DISCUSSION}

Daily, we are confronted with multiple types of malocclusions, and we focus on diligent diagnosis, for which, we must consider the importance of studying the position and its relationship with craniofacial structures. The natural position of the head should be suggested as the basis for the analysis of postural craniofacial morphology (Showferty et al., 1983), where the sagittal ratio of the bony facial structure, such as the maxillae and mandible on the skull, are described by class skeletal types I, II, and III (Vellini, 2002). Authors, such as Bricot (2004), state that skeletal classes have different patterns of head and cervical posture.

To establish the skeletal class, ANB angle and Wits appraisal variables were used which showed a high correlation (0.7895), showing the association of these additional variables, as a good proposal in cephalometric diagnosis. This together with the positive correlation $(0.6384)$ between cervical curvature and $\mathrm{C} 0-\mathrm{C} 1$ distance, inversely proportional to that observed among ANB angle and cervical curvature (-0.4328).

In the descriptive characteristics, two averages were altered from the norm. Only variables $\mathrm{C} 0-\mathrm{C} 1$ distance, angle posterior-inferior angle, and Wits appraisal showed an average within the normal range but with large standard deviations, which probably can lead to false-positive diagnoses. There is evidence that deviations from normal craniocervical angulation of the skull and spine could be correlated with high levels of anxiety (Ohno et al., 2004).

In relation to the hyoid triangle variable, most subjects had alterations in the hyoid bone position in relation to determining the physiological curvature of the cervical spine, where only $21.4 \%$ had a vertical relationship of the hyoid bone below the plane $\mathrm{C} 3$-Retrognation ( $\mathrm{RGn}$ ), differing significantly with $60 \%$ reported by Henriquez et al. (2003) in a young male, of ethnic Mapuche population.

We observed a significant difference when analyzing the cervical curvature by sex; however, both averages turned out to have more features for correction of cervical spine, with the female subjects being the most affected. There also were significant differences in the posterior-inferior angle variable. Note that in the male group, the average value was within the norm but in its highest range, whereas the female group showed an average within the norm but in its lowest range, suggesting a posterior rotation of the skull. For the ANB angle, both groups exhibit characteristics of skeletal class II.

Depending on the skeletal class measured by the ANB angle, the analysis was statistically significant in relation to the association of cervical curvature and $\mathrm{C} 0-\mathrm{C} 1$ distance, suggesting that the percentages of subjects' class I, II, and III with abnormal cervical curvature subjects differed from the normal cervical curvature. Also, the percentages of subjects skeletal class I, II and III showed C0-C1 normal and abnormal distances .

D'Attilio et al., in a study on 120 children, reported that class III children had a more rectified cervical curvature compared with the subjects of other skeletal classes, whereas class skeletal II had more extensive head and a more lordotic cervical curvature-similar to those obtained in our study. Recently, a positive association between the counterclockwise rotation of the skull, a $\mathrm{C} 0-\mathrm{C} 1$ distance, and decreased skeletal class III has been reported (Aldana et al., 2011). These authors reported an association between hyoid triangle and class skeletal II, a statement that agrees with our results, because subjects with skeletal class II in the present study showed the largest percentage of the hyoid triangle with abnormal characteristics. When performing the same analysis previously discussed, that is, comparing cervical curvature, $\mathrm{C} 0-\mathrm{C} 1$ distance, angle and posterior hyoid triangle, although measured using the Wits appraisal, we found no significant differences.

In studying the association, there seems to be a tendency for subjects to be classified class I with normal values for the variables under study, but class II subjects tend to show more abnormal values of the variables studied. Important, because there were few studies on the subject in question, it is necessary to combine metrics to make comparative measurements.

In conclusion, the skeletal class analysis by ANB angle showed that both groups have class II skeletal features; however, by Wits appraisal, male subjects have a class I tendency, whereas the female group showed a class II tendency and a directly proportional correlation between cervical curvature and distance $\mathrm{C} 0-\mathrm{C} 1$ variables; thus, it is recommended parameter ANB angle and Wits appraisal to are used to establish classes that provide complementary information in each case. Taking into account that many of the subjects measured in our study are in still in the developmental stage, it is important that cervical curvature and ANB angle had abnormal mean values. Only $\mathrm{C} 0-\mathrm{C} 1$ distance, posterior-inferior angle, and Wits appraisal variables were within the norm. The cervical curvature showed a trend of variation with respect to sex, whereas the average values were found to have cervical rectification characteristics mainly in the female group and showed an average lowerthan-the-standard posterior-inferior angle, which shows a greater posterior rotation of the skull. Importantly, the results should be taken with caution and should not be considered as the only diagnosis but rather as a complementary study to the other determinants of craniofacial growth and development. 
GARCÍA, N.; SANHUEZA, A.; CANTÍN, M. \& FUENTES, R. Evaluación de la postura cervical en sujetos adolescentes con clase esqueletal I, II y III. Int. J. Morphol., 30(2):405-410, 2012.

RESUMEN: El objetivo de este estudio fue investigar si existen diferencias significativas en la postura cervical de pacientes adolescentes con diferente clase esqueletal. Veintiocho adolescentes ( 21 hombres y 7 mujeres, edad promedio 13,6 años, DE $\pm 3,2)$ fueron admitidos para este estudio y el tratamiento de ortodoncia. Fueron seleccionados sujetos sin antecedentes de tratamiento ortodóncico, ortopédico o quirúrgico previo, asimetría facial, bruxismo, obstrucción nasal, dolor orofacial y disfunción de la articulación temporomandibular. Para cada caso se tomaron radiografías laterales de cráneo y los sujetos fueron divididos en tres grupos basados en su clase esqueletal según el ángulo ANB y la evaluación de Wits. Los trazados cefalométricos incluyeron las variables postural cervical y curvatura cervical. Mediante el análisis de correlación de Pearson (usando las variables como contínuas), se encontró una alta relación lineal entre las variables ángulo ANB y evaluación de Wits $(0,7895)$ y entre curvatura cervical y la distancia C0-C1 $(0,6384)$. Se observó significancia estadística entre el ángulo ANB y las variables curvatura cervical $(\mathrm{p}=0,039)$ y distancia $\mathrm{C} 0-\mathrm{C} 1$ ( $\mathrm{p}=0,045)$, mientras que la evaluación de Wits no mostró una asociación con las variable de estudio ( $>>0,05$ ). La curvatura cervical fue diferente entre las clases esqueletales, sin embargo, ambos promedios resultaron tener rectificación cervical, siendo las mujeres claramente más afectadas, junto con un promedio menor del ángulo postero-inferior en relación al estándar, lo que muestra una rotación más posterior del cráneo. La postura cráneocervical parece estar fuertemente asociada con la postura sagital, así como la estructura vertical de la cara, siendo estos datos complementarios a otros determinantes del crecimiento y desarrollo craneofacial.

PALABRAS CLAVE: Postura cervical; Clase esqueletal; Alteraciones cráneocervicales; Curvatura cervical.

\section{REFERENCES}

Aldana, P. A.; Báez, R. J.; Sandoval, C. C.; Vergara, N. C.; Cauvi, L. D. \& Fernández de la Reguera, A. Asociación entre maloclusiones y posición de la cabeza y cuello. Int. J. Odontostomat., 5:119-25, 2011.

Amis, T. C.; O'neill, N. \& Wheatley, J. R. Oral airway flow dynamics in healthy humans. J. Physiol., 515:293-8, 1999.

Bergamini, M.; Pierleoni, F.; Gizdulich, A. \& Bergamini, C. Dental occlusion and body posture: a surface EMG study. Cranio, 26:2532, 2008.

Bricot, B. Posturología. 3a ed. São Paulo, Icone, 2004.

D'attilio, M.; Caputi, S.; Epifania, E.; Festa, F. \& Tecco, S. Evaluation of cervical posture of children in skeletal class I, II, and III. Cranio, 23:219-28, 2005.

Friedman, M. H. \& Weisberg, J. The craniocervical connection: a retrospective analysis of 300 whiplash patients with cervical and temporomandibular disorders. Cranio, 18:163-7, 2000.

Fuentes, R.; Henríquez, J.; Sandoval, P. \& Matamala, F. Estudio anatomo-radiológico de la región craneocervical en 60 estudiantes de la Universidad de La Frontera. Rev. Med. Chil., 124:14838, 1996.

Gonzalez, H. E. \& Manns, A. Forward head posture: its structural and functional influence on the stomatognathic system, a conceptual study. Cranio, 14:71-80, 1996

Gregoret, J. Ortodoncia y cirugía ortognática, Diagnóstico y planificación de tratamiento. Barcelona, Publicaciones Médicas, 1997.

Henríquez, J.; Fuentes, R.; Sandoval, P. \& Muñoz, A. Análisis de la estabilidad ortostática cráneocervical en adultos jóvenes mapuches. Int. J. Morphol., 21:149-53, 2003.

Huggare, J. Postural disorders and dentofacial morphology. Acta Odontol. Scand., 56:383-6, 1998.
Jacobson, A. The "Wits" appraisal of jaw disharmony. Am. J. Orthod., 67:125-38, 1975 .

Ohno, H.; Wada, M.; Saitoh, J.; Sunaga, N. \& Nagai M. The effect of anxiety on postural control in humans depends on visual information processing. Neurosci. Lett., 364:37-9, 2004.

Penning, L. Functional Pathology of the Cervical Spine. Amsterdam, Excerpta Medica, 1968.

Rocabado, M. Análisis biomecánico craneocervical a través de una telerradiografía lateral. Rev. Chil. Ortod., 1:42-52, 1984.

Santander, H.; Miralles, R.; Perez, J.; Valenzuela, S.; Ravera, M. J.; Ormeno, G. \& Villegas, R. Effects of head and neck inclination on bilateral sternocleidomastoid EMG activity in healthy subjects and in patients with myogenic cranio-cervical-mandibular dysfunction. Cranio, 18:181-91, 2000.

Scutellari, P. N.; Capurso, U.; Orzincolo, C.; Rotolo, L. \& Calura, G. Radiodiagnosis of orthodontic and dysfunctional anomalies of the stomatognathic system: analysis of a sample of 204 patients. Radiol. Med., 80:834-40, 1990.

Solow, B. \& Sonnesen, L. Head posture and malocclusions. Eur. J. Orthod., 20:685-93, 1998.

Sowferty, K. J.; Vig, P. S. \& Matteson, A. S. Simple method for taking natural-head position cephalograms. Am. J. Orthod., 83:495-500, 1983.

Vellini, F. Ortodoncia, diagnóstico y planificación clínica. 1a ed. São Paulo, Artes Médicas, 2002.

Correspondence to:

Ramón Fuentes

Dentistry Department

Faculty of Medicine

Universidad de La Frontera

Av. Francisco Salazar 01145

Temuco - CHILE

Email: rfuentes@ufro.cl

Received: 10-12-2011

Accepted: 10-01-2012 